UDC 658:338

JEL Classification: D23, M12, M10

http://doi.org/10.21272/mmi.2019.1-18

Jana Marie Safrankova,

Ph.D., Associate Professor, College of Regional Development and Banking Institute - AMBIS, Czech Republic Martin Sikyr,

Ph.D., College of Regional Development and Banking Institute - AMBIS, Czech Republic

\title{
Management and diversity management in SMEs in the Czech Republic
}

Abstract. It is obvious that small and medium-sized enterprises (SMEs) play an important role in economic development and many of them consider qualified and experienced people to be the most important source for achieving expected goals. To apply and develop knowledge, skills and abilities of different people, SMEs should apply strategies, policies and practices on diversity management to create appropriate and attractive job opportunities and working conditions for different generations of people and ensure effective use and development of their potential. Based on the authors' scientific cooperation and research results the goal of the paper is to explore and compare some approaches to people and diversity management in six Czech profit SMEs. The paper summarizes the results of the authors' questionnaire survey on managing people and diversity management in six Czech profit SMEs. The survey was conducted from March to April 2018. The relevant data were obtained from 258 respondents. The respondents were characterized by the type of business, the gender, the age, and nationality. The data analysis was based on the calculation of relative frequencies (as a share from the total number of respondents) and the evaluation of the dependence of responses on gender (male and female respondents) using contingency tables and chi-square tests of independence. Based on the results, the paper aims to answer what the current problems in diversity management in Czech SMEs are and how Czech SMEs do prevent gender and age discrimination of employees. The analysis of people and diversity management policies and practices is focused on employee selection, employee compensation, and discrimination in the workplace. The results show that surveyed SMEs are able to effectively and efficiently prevent gender and age discrimination of employees, however, they should focus more on creating and maintaining employment opportunities and working conditions with regard to the natural diversity of people. Diversity management policies and practices in SMEs should be focused on diverse employee selection, evaluation, compensation, and development. These activities may enable SMEs to attract, employ and develop gender and age diverse groups of people with different knowledge, skills and abilities that may help SMEs to achieve expected organizational results through achieving desired employee results. The results are worth attention from managers of SMEs who are responsible for managing and leading other employees. The results open up new possibilities for further research in the field of diversity management and dealing with gender and age discrimination of employees.

Keywords: Czech Republic, diversity management, organization management; people management, small and medium-sized enterprises.

Introduction. Small and medium-sized enterprises (SMEs) constitute an important part in economic development of any given country and contribute considerably to regional economic development by creating new jobs, providing investment opportunities and forming the economic capital and potential required for sustainable economic growth (Janda et al., 2013; Koudelkova and Svobodova, 2014; Belas et al., 2015).

SMEs constitute the main focus in shaping business development policies in the European Union (EU) coming to the forefront of the world economy (Kozubikova et al., 2015; Ehrenberger et al., 2015; Machova et al., 2016; Ruchkina et al., 2017). According to many researchers, by 2020 more than $50 \%$ of all workplaces will be occupied by sole traders and freelancers.

Many enterprises including SMEs consider experienced people to be the most important source and require people with the necessary knowledge, skills and abilities to help them to achieve expected goals. To apply and develop knowledge, skills and abilities of different people, the enterprises should apply

Cite as: Safrankova, J. M., \& Sikyr, M. (2019). Management and Diversity Management in SMEs in The Czech Republic. Marketing and Management of Innovations, 1, 221-228. http://doi.org/10.21272/mmi.2019.1-18 
strategies, policies and practices on diversity management to create appropriate and attractive job opportunities and working conditions for different generations of people and ensure effective use and development of their potential. In the case of diversity management, enterprises should create age-old, diverse workgroups, bringing together young people's new knowledge of the life and work experience of other people in the enterprise. (Okon-Horodynska et al., 2016)

The goal of the paper is to explore and compare some approaches to people and diversity management in six Czech profit small and medium-sized enterprises (SMEs). The paper summarizes the results of the authors' questionnaire survey on managing people and diversity management in six Czech profit SMEs. The survey was conducted from March to April 2018. The relevant data were obtained from 258 respondents. The paper aims to answer the following questions: What are the current problems in diversity management in Czech SMEs? How do Czech SMEs prevent gender and age discrimination of employees?

The paper is divided into four parts, including literature review, research methodology, empirical results and discussion, and conclusion. The literature review summarizes the results of previous studies on diversity management with the focus on small and medium-sized enterprises. The research methodology provides a description of the authors' questionnaire survey on managing people and diversity management in six Czech profit SMEs. The empirical results and discussion present and discuss results of the authors' questionnaire survey on managing people and diversity management in six Czech profit SMEs, it assesses and critiques the authors' findings and compared them to findings of other researchers. The conclusion includes the general summary of the paper, implications and recommendations for practice, research limitations, and suggestions for future research.

Literature Review. With demographic shifts, international labour mobility, and the blurring of geographical boundaries, workforce diversity and diversity management have assumed an important role in business activities (Manoharan and Singal, 2017). Workforce diversity and diversity management are reported to be crucial factors that positively influence organizational performance (Cho et al., 2017). In the Czech Republic, workforce diversity and diversity management have become very important and relevant in business management and development named after the Czech Republic joined the European Union (Eger and Ludvik, 2014).

Corporate investments in diversity management programs have increased over the past two decades mainly because investing in diversity management influences organizational attraction (Madera et al., 2018). Diversity management programs serve as a source of competitive advantage, but organizations must employ people who will fit in and support these programs. Organizational human resource management activities should highlight the support of diversity management programs and all stakeholders should benefit from these programs (Madara, 2018). Diversity management practices including diversity recruitment, training, pay, and promotion across minority or other disadvantaged groups are positively associated with higher labour productivity and workforce innovation and lower voluntary employee turnover (Armstrong et al., 2010).

In today's international context people are becoming more positive towards diversity and introducing diversity management policies and practices across national borders and organizations might not meet as much resistance as previously anticipated (Traavik and Adavikolanu, 2016). Diversity management offers competitive advantages, but it is mostly a management tool for bigger organizations (Ozdemir, 2017). Small and medium-sized organizations tend to downplay diversity management issues although recent research findings indicate that managing diversity through introducing proven diversity management practices may improve organizational performance and achieve sustained competitive advantage. But ignoring the positive effects of a diverse workforce by small and medium-sized organizations may lead to loss of business opportunities that such a workforce is noted to bring along (Snellman, 2016).

From an age perspective, the goal of diversity management is to gain a competitive advantage by 
employing people of all ages, which requires a change in some stereotypes related to the employment of young and older people. It is important that everyone has the opportunity to use their potential and has not been disadvantaged due to their age (Poczatkova and Kribikova, 2017). Ageing diverse working groups have diverse knowledge, skills and abilities that bring added value to the workplace and play a key role in achieving organizational success. Age-diversified working groups are more experienced, less experienced, more flexible, and more productive than younger or older working groups. In addition, agerelated working groups have the opportunity to communicate with different generations of co-workers, improving their relationships as well as their morale and motivation, making the organization more attractive to employees and other stakeholders. (Horvathova et al., 2016)

Diversity management is based on the benefits of differences, which is not the same as ensuring equal opportunities that seek to reduce discrimination and which is based on the assumption that people should be integrated into the organization, often relying on positive discrimination. Diversity Management recognizes that there are differences between people and that these differences, when properly managed, allow work to be done more effectively and more effectively. Diversity management, therefore, does not only deal with discrimination issues but focuses primarily on awareness of the differences between people. (Armstrong and Taylor, 2015)

People working in organizations applying diversity management principles are often members of diverse working groups in which both mutual enrichment and empowerment and mutual tolerance may occur (Kunz, 2012). The application of the principles of diversity management increases the potential of working group creativity and finding new solutions, precisely because of the wider range of views, views and ideas of members of diverse working groups. Well-managed diversity management can positively influence the results of individuals, teams and organizations (Parker et al., 2017).

One of the possible results of diversity management is the increase of justice in the organization (Kim and Park, 2016). This is not about the earmarking of groups that need more respect and tolerance but about the natural integration of diversity into everyday life in an organization (Howarth and Andreouli, 2016). From a gender perspective, nowadays women more often lead teams, make plans as well as important decisions (Petkeviciute and Streimikiene, 2017). The main differences of wages, differences between men and women are: as it comes to rate and type of human capital, rewarding for the same work, choice of work type, and accessibility of work types (Krizkova and Pavlica, 2004).

Wage discrimination is very closely connected to the above-described gender segregation because it represents one of the main differences in wages levels at the labour market. It is generally valid that strictly men's jobs or jobs where men prevail are financially better evaluated (Havelkova, 2007). The connection between wage discrimination and gender segregation is inseparable. Consequences of such connection are very serious - they cause lower life level of some groups of women or causes children poverty (directly based on mothers/women disadvantaging (Poczatkova and Kribikova, 2017).

Methodology and research methods. The paper summarizes the results of the authors' questionnaire survey on managing people and diversity management in six Czech profit SMEs. Based on the results, the paper aims to answer the following questions: What are the current problems in diversity management in Czech SMEs? How do Czech SMEs prevent gender and age discrimination of employees? The survey was conducted from March to April 2018. The questionnaire included 112 multiple choice questions focused on people and diversity management practices.

The relevant data were obtained from 258 respondents. The respondents were characterized by the type of business (5\% accounting, 24\%wellness, $20 \%$ education, $20 \%$ recruitment agency $1,19 \%$ recruitment agency $2,12 \%$ food), the gender ( $46 \%$ male, $54 \%$ female), the age ( $37 \% 25$ years or less, $54 \%$ between 26 and 54 years, $9 \% 55$ years or more), and the nationality ( $93 \%$ Czechs and Slovaks, $7 \%$ other nationalities). The data analysis was based on the calculation of relative frequencies (as a share from the total number of respondents) and the evaluation of the dependence of responses on gender 
(male and female respondents) using contingency tables and chi-square tests of independence.

Results. This part presents and discusses the results of the authors' questionnaire survey on managing people and diversity management in six Czech profit SMEs. It aims to answer what the current problems in diversity management in Czech SMEs are and how Czech SMEs do prevent gender and age discrimination of employees. The analysis of people and diversity management policies and practices is focused on employee selection, employee compensation, and discrimination in the workplace.

In terms of employee selection, $82 \%$ of respondents were interviewed before taking up employment. Most respondents said that the interview was pleasant and friendly. Only $6 \%$ of interviewed respondents perceived the interview as discriminatory in terms of gender or age. Other respondents perceived their interviews as neutral or objective. The data analysis showed no significant difference between male and female respondents $(p<0.05)$. Firstly, we tested the null hypothesis that there is no difference between male and female respondents regarding their perception of gender discrimination during the interview (Table 1). Since the test statistics were lower than the critical value, we failed to reject the null hypothesis in favour of the alternative hypothesis. In other words, there was no difference between male and female respondents regarding their perception of gender discrimination during the interview.

Table 1. Respondents' perception of gender discrimination during the interview

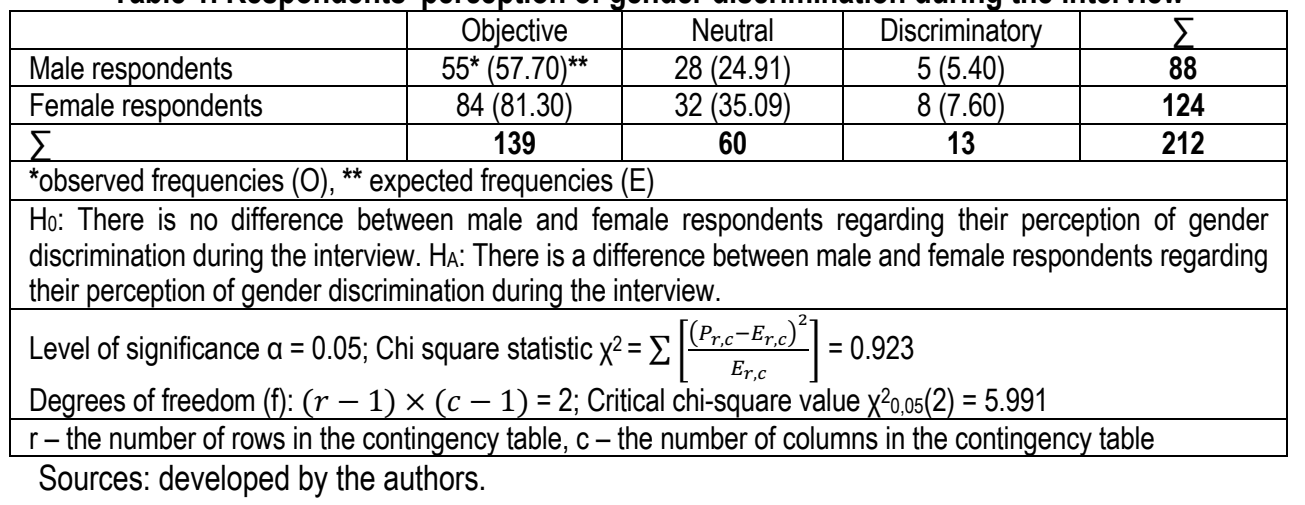

Secondly, we tested the null hypothesis that there is no difference between male and female respondents regarding their perception of age discrimination during the interview (Table 2).

Table 2. Respondents' perception of age discrimination during the interview

\begin{tabular}{|c|c|c|c|c|}
\hline & Objective & Neutral & Discriminatory & $\Sigma$ \\
\hline Male respondents & $59^{*}(64.58)^{\star *}$ & $17(14.26)$ & $8(5.15)$ & 84 \\
\hline Female respondents & $104(98.42)$ & $19(21.74)$ & $5(7.85)$ & 128 \\
\hline$\Sigma$ & 163 & 36 & 13 & 212 \\
\hline \multicolumn{5}{|c|}{${ }^{*}$ observed frequencies $(O),{ }^{* *}$ expected frequencies $(\mathrm{E})$} \\
\hline \multicolumn{5}{|c|}{$\begin{array}{l}H_{0}: \text { There is no difference between male and female respondents regarding their perception of gender } \\
\text { discrimination during the interview. } H_{A} \text { : There is a difference between male and female respondents regarding } \\
\text { their perception of gender discrimination during the interview. }\end{array}$} \\
\hline \multicolumn{5}{|c|}{$\begin{array}{l}\text { Level of significance } a=0.05 \text {; Chi square statistic } \chi^{2}=\sum\left[\frac{\left(P_{r, c}-E_{r, c}\right)^{2}}{E_{r, c}}\right]=4.279 \\
\text { Degrees of freedom }(f):(r-1) \times(c-1)=2 \text {; Critical chi-square value } \chi^{2} 0,05(2)=5.991\end{array}$} \\
\hline
\end{tabular}

Sources: developed by the authors.

Since the test statistics were lower than the critical value, we failed to reject the null hypothesis in 
favour of the alternative hypothesis. In other words, there was no difference between male and female respondents regarding their perception of gender discrimination during the interview. In terms of employee compensation, $24 \%$ of respondents stated that they are dissatisfied with their wages, $17 \%$ of respondents stated that they do not think their wage is comparable to that of their colleagues in a similar position, and $10 \%$ of respondents stated that they feel wage discrimination because they were male or female. The data analysis showed a significant difference between male and female respondents $(p<0.05)$. We tested the null hypothesis that there is no difference between male and female respondents regarding their feeling of wage discrimination (Table 3). Since the test statistics were higher than the critical value, we rejected the null hypothesis in favour of the alternative hypothesis. In other words, there was a difference between male and female respondents regarding their feeling of wage discrimination.

Table 3. Respondents' feeling of wage discrimination

\begin{tabular}{|c|c|c|c|c|}
\hline & Yes & Neither yes nor no & No & $\sum$ \\
\hline Male respondents & $10^{*}(11.43)^{* *}$ & $15(9.60)$ & $93(96.96)$ & 118 \\
\hline Female respondents & $15(13.57)$ & $6(11.40)$ & $119(115.04)$ & 140 \\
\hline$\sum$ & 25 & 21 & 212 & 258 \\
\hline \multicolumn{5}{|c|}{ *observed frequencies $(\mathrm{O}),{ }^{* *}$ expected frequencies $(\mathrm{E})$} \\
\hline \multicolumn{5}{|c|}{$\begin{array}{l}\mathrm{H}_{0} \text { : There is no difference between male and female respondents regarding their perception of gender } \\
\text { discrimination during the interview. } \mathrm{H}_{\mathrm{A}} \text { : There is a difference between male and female respondents regarding } \\
\text { their perception of gender discrimination during the interview. }\end{array}$} \\
\hline \multirow{2}{*}{\multicolumn{5}{|c|}{$\begin{array}{l}\text { Level of significance } a=0.05 ; \text { Chi square statistic } X^{2}=\sum\left[\frac{\left(P_{r, c}-E_{r, c}\right)^{2}}{E_{r, c}}\right]=6.215 \\
\text { Degrees of freedom }(f):(r-1) \times(c-1)=2 ; \text { Critical chi-square value } X^{2} 0,05(2)=5.991\end{array}$}} \\
\hline & & \multicolumn{3}{|c|}{$r$ - the number of rows in the contingency table, $c$ - the number of columns in the contingency table } \\
\hline
\end{tabular}

Sources: developed by the authors.

In terms of discrimination in the workplace, only $6 \%$ of respondents stated that they experienced discrimination in the workplace. $70 \%$ of respondents stated that they know how to deal with discrimination in the workplace. $49 \%$ of respondents stated that they are satisfied with the employer's approach to discrimination in the workplace. The data analysis showed no significant difference between male and female respondents $(p<0.05)$. We tested the null hypothesis that there is no difference between male and female respondents regarding their satisfaction with the employer's approach to discrimination in the workplace (Table 4).

Table 4. Respondents' satisfaction with the employer's approach to discrimination

\begin{tabular}{|l|c|c|c|c|}
\hline & Yes & Neither yes nor no & No & $\sum$ \\
\hline Male respondents & $66^{*}(57.63)^{* *}$ & $46(53.97)$ & $6(6.40)$ & 118 \\
\hline Female respondents & $60(68.37)$ & $72(64.03)$ & $8(7.06)$ & 140 \\
\hline$\sum$ & $\mathbf{1 2 6}$ & $\mathbf{1 1 8}$ & 14 & $\mathbf{2 5 8}$ \\
\hline
\end{tabular}

*observed frequencies $(\mathrm{O}),{ }^{* *}$ expected frequencies $(\mathrm{E})$

$\mathrm{H}_{0}$ : There is no difference between male and female respondents regarding their perception of gender discrimination during the interview. $\mathrm{H}_{\mathrm{A}}$ : There is a difference between male and female respondents regarding their perception of gender discrimination during the interview.

Level of significance $a=0.05$; Chi square statistic $\chi^{2}=\sum\left[\frac{\left(P_{r, c}-E_{r, c}\right)^{2}}{E_{r, c}}\right]=4.457$

Degrees of freedom $(f):(r-1) \times(c-1)=2$; Critical chi-square value $\chi^{2} 0,05(2)=5.991$

$r$ - the number of rows in the contingency table, $c$ - the number of columns in the contingency table

Sources: developed by the authors. 
Since the test statistics were lower than the critical value, we failed to reject the null hypothesis in favour of the alternative hypothesis. In other words, there was no difference between male and female respondents regarding their satisfaction with the employer's approach to discrimination in the workplace.

Based on the authors' findings and findings of other researchers in terms of the approach to diversity management in SMEs, diversity management policies and practices in Czech SMEs should be focused on creating and maintaining employment opportunities and working conditions with regard to the natural diversity of people and on preventing gender and age discrimination of employees (Krizkova and Pavlica, 2004). From the perspective of the gender and age of people, the aim of diversity management should be to gain a competitive advantage by employing men and women of all ages (Madara, 2018). But this requires changing some stereotypes associated with the employment of men and women as well as young and older people.

In terms of age, young people usually do not meet the employers' requirements for professional skills and experience, as well as social behaviour and professional motivation. Older people (aged 50 and over) are usually seen as loyal and hardworking, but inflexible, ineffective and unpromising (Nemec and Surynek, 2015). This leads to the fact that employers are not willing to invest in them. In addition, many young and older people believe that the age alone is a barrier for getting a job, but the fact is that employers can really benefit from an age-diverse workforce, mixing the new ideas of young people with the life experience of older people.

Gender and age diverse groups of people have various knowledge, skills and abilities that add value to the workplace and play a key role in achieving the success of the organization. Gender and age diverse groups of people are more experienced, have lower absenteeism, and are more flexible and often more productive than male or female as well as younger or elder groups of workers. In addition, gender and age diverse groups of people have a chance to interact with different co-workers, which improves their relationships and understanding, as well as their morale and motivation, and makes the organization more attractive to workers and other stakeholders (Horvathova et al., 2016).

Conclusions. The results of the authors' survey on managing people and diversity management in six Czech profit SMEs show that surveyed SMEs are able to effectively and efficiently prevent gender and age discrimination of employees, however, they should focus more on creating and maintaining employment opportunities and working conditions with regard to the natural diversity of people. It is obvious that also SMEs can gain a competitive advantage by employing men and women of all ages.

Diversity management policies and practices in SMEs should be focused on diverse employee selection, evaluation, compensation, and development. These activities may enable SMEs to attract, employ and develop gender and age diverse groups of people with different knowledge, skills and abilities that may help SMEs to achieve expected organizational results through achieving desired employee results.

The authors' survey is quite unique by its focus on diversity management and prevention of gender and age discrimination of employees in Czech SMEs. Similar surveys are quite rare. The specific focus on Czech SMEs, as well as the relatively low number of respondents, does not allow authors to draw general conclusions. However, the current authors' survey results are worth attention from managers of SMEs who are responsible for managing and leading other employees. The current authors' survey results open up new possibilities for further research in the field of diversity management and dealing with gender and age discrimination of employees.

Author Contributions: Conceptualization, J. M. S. and M. S.; methodology, J. M. S. and M. S.; formal analysis, J. M. S. and M. S.; investigation, J. M. S. and M. S.; resources, J. M. S. and M. S.; writingoriginal draft preparation, J. M. S. and M. S.

Funding: This research was funded by European social fund, grant number CZ.03.1.51/0.0/0.0/16_051/0006318. 


\section{References}

Armstrong, C., Flood, P. C., Guthrie, J. P., Liu, W. C., MacCurtain, S., \& Mkamwa, T. (2010). The impact of diversity and equality management of firm performance: Beyond high performance work systems. Human Resource Management, 49(6), 977-998. Armstrong, M., \& Taylor, S. (2015). Rizeni lidskych zdroju. Moderni pojeti a postupy. Prague: Grada Publishing.

Belas, J., Bilan, Y., Demjan, V., \& Sipko, J. (2015). Entrepreneurship in SME segment: case study from the Czech Republic and Slovakia. Amfiteatru Economic, 17(38), 308-326.

Eger, L., \& Indruchova, Z. (2014). Diversity management - perceptions and attitudes by Czech managers. E \& M Ekonomie a management, 17(1), 73-81.

Ehrenberger, M., Koudelkova, P., \& Strielkowski, W. (2015). Factors influencing innovation in small and medium enterprises in the Czech Republic. Periodica Polytechnica. Social and Management Sciences, 23(2), 73-83. doi: 10.3311/PPso.7737. Havelkova, B. (2007). Rovnost v odmenovani zen a muzu. Prague: Auditorium.

Horvathova, P., Blaha, J., \& Copikova, A. (2016). Rizeni lidskych zdroju. Nové trendy. Prague: Management Press.

Howarth, Caroline, Andreouli, Eleni, 2016. Nobody wants to be an outsider: From diversity management to diversity engagement. Political Psychology, 37(3), 327-340.

Cho, S., Kim, A., \& Barak, M. E. M. (2017). Does diversity matter? Exploring workforce diversity, diversity management, and organizational performance in social enterprises. Asian Social Work and Policy Review, 11(3), 193-204. doi: 10.1111/aswp.12125. Janda, K., Rausser, G., \& Strielkowski, W. (2013). Determinants of profitability of Polish rural micro-enterprises at the time of EU Accession. Eastern European Countryside, 19, 177-217. doi: 10.2478/eec-2013-0009

Madera, J. M. (2018). Situational perspective taking as an intervention for improving attitudes toward organizations that invest in diversity management programs. Journal of Business and Psychology, 33(3), 423-442. doi 10.1007/s10869-017-9502-0.

Kim, S., Park, S. (2016). Organizational justice as an outcome of diversity management for female employees: Evidence from US federal agencies. Transylvanian Review of Administrative Sciences, 49E, 41-59.

Koudelkova, P., \& Svobodova, P. (2014). Knowledge creation \& sharing as essential determinants of SMEs innovation. International Economics Letters, 3(1), 12-20. doi: 10.24984/iel.2014.3.1.3.

Kozubikova, L., Belas, J., Bilan, Y., \& Bartos, P. (2015). Personal characteristics of entrepreneurs in the context of perception and management of business risk in the SME segment. Economics \& Sociology, 8(1), 41-54. doi: 10.14254/2071-789X.2015/8-1/4. Press. Krizkova, A., \& Pavlica, K. (2004). Management genderovych vztahu: Postaveni zen a muzu v organizaci. Prague: Management

Kunz, V. (2012). Spolecenska odpovednost firem. Prague: Grada Publishing.

Madera, J. M., Dawson, M., \& Neal, J. A. (2018). Why investing in diversity management matters: organizational attraction and person-organization fit. Journal of Hospitality \& Tourism Research, 42(6), 931-959. doi 10.1177/1096348016654973.

Machova R., Huszarik E. S., \& Simonova M. (2016). Selected aspects of innovation policy for small and medium sized enterprises. Journal of International Studies, 9(2), 219-232.

Manoharan, A. \& Singal, M. (2017). A systematic literature review of research on diversity and diversity management in the hospitality literature. International Journal of Hospitality Management, 66, 77-91. doi 10.1016/j.jijhm.2017.07.002.

Nemec, O., \& Surynek, A. (2015). Age management as a part of corporate social responsibility, In Loster, T., \& Pavelka, T. (Eds.). The 9th International Days of Statistics and Economics, 1180-1190.

Okon-Horodynska, E., Zachorowska-Mazurkiewicz, A., Wisla, R., Sierotowicz, T. (2016). Gender, innovative capacity, and the process of innovation: a case of Poland. Economics and Sociology, 9(1), 252-263. doi: 10.14254/2071- 789X.2016/9-1/17.

Ozdemir, F. (2017). Managing diversity becomes managing capabilities. In Soliman, K. S. (Ed.). 29th International-BusinessInformation-Management-Association Conference. Austria, Vienna, 2970-2981.

Snellman, L. (2016). Diversity management: Adding value in family business? In Bratianu, C.; Zbuchea, A.; Pinzaru, F.; Leon, R. D.; \& Vatamanescu, E. M. (Eds.). 4th International Academic Conference Strategica. Romania, Bucharest, 844-859.

Parker, J., Arrowsmith, J., Haar, J. (2017). Diversity management in New Zealand: Towards an empirically-based model of employer propensity to manage diversity. Labour \& Industry - A Journal of the Social and Economic Relations of Work, 27(1), 3455.

Petkeviciute, N., Streimikiene, D. (2017). Gender and sustainable negotiation. Economics and Sociology, 10(2), 279-295. doi 10.14254/2071-789X.2017/10-2/21.

Poczatkova, B., \& Kribikova, P. (2017). Gender inequality in the field of science and research. Journal of International Studies, 10(1), 267-276. doi:10.14254/2071-8330.2017/10-1/19.

Ruchkina, G., Melnichuk, M., Frumina, S., \& Mentel, G. (2017). Small and medium enterprises in regional development and innovations. Journal of International Studies, 10(4), 259-271. doi:10.14254/2071-8330.2017/10-4/20.

Traavik, L. E. M., \& Adavikolanu, A. V. (2016). Attitudes towards diversity evidence from business school students from Norway, India and the Czech Republic. Cross Cultural \& Strategic Management, 23(3), 450-466. doi 10.1108/CCSM-12-2013-0189. 
Я. М. Сафранкова, Ph.D., доцент, Iнститут регіонального розвитку та банківської справи AMBIS (Чехія);

M. Сікур, Ph.D., Iнститут регіонального розвитку та банківської справи - AMBIS (Чехія).

Менеджмент та диверсифікаційний менеджмент малих та середніх підприємств: досвід Чехії

Малі та середні підприємства (МСП) є основою економічного зростання країни. При цьому ефрективність ффункціонування МСП залежить від рівня кваліфрікації їх працівників, що, у свою чергу, виступає основною рушійною силою досягнення запланованих МСП цілей. Так, МСП повинні на постійній основі впроваджувати стратегії диверсифрікаційного менеджменту з метою розвитку знань, вмінь та навичок своїх працівників. Основною метою диверсифбікаційного менеджменту $є$ формування умов праці, враховуючі відповідні потреби різних груп працівників (әнучкий робочий графрік, самореалізація та розвиток, тощо). Головною метою статті $\epsilon$ аналіз, систематизація та порівняння основних підходів до управління трудовими ресурсами та диверсифрікаційного менеджменту шести основних прибуткових МСП Чехії. Авторами систематизовано результати анкетування (258 респондентів) щодо ефрективності управління трудовими ресурсами та диверсифрікаційного менеджменту на обраних МСП. Опитування проводилось у березні 2018 року. Критеріями відбору респондентів даного дослідження були: вид діяльності, стать, вік та національність. Для перевірки гіпотез дослідження авторами розраховано показник відносної частоти (як частка від загальної сукупності респондентів), оцінено вплив гендерного фактору за допомогою фракторної таблиці та критерію хі-квадрат Пірсона. На основі отриманих результатів авторами визначено основні проблеми диверсифрікаційного менеджменту МСП у Чехії, а також перспективні напрями мінімізації вікової та гендерної дискримінації. Таким чином, аналіз досвіду управління трудовими ресурсами та використання диверсифрікаційного менеджменту у діяльності МСП свідчить про те, що МСП фокусуюся на наступних фракторах: відбір співробітників, оплата праці та дискримінація на робочому місці. Отримані результати дослідження свідчать про те, що проаналізовані МСП спроможні ефективно та дієво запобігати появі гендерної та вікової дискримінації співробітників, однак вони більш зосередженні на створенні та підтримці можливостей працевлаштування та формуванні сприятливих умов праці. Автори наголошують, що політика та практика диверсифрікаційного менеджменту МСП мають бути сконцентровані на наступних заходах: диверсифрікованому підході при у ході відбору співробітників, заробітній платі та саморозвитку. Автори зазначають, що вищезазначені заходи можуть мінімізувати гендерну нерівність, вирішити проблеми різновіковості працівників з різним рівнем знань, навичок та вмінь. Отримані результати дослідження можуть стати корисними для менеджерів, що відповідають за ефрективність управління трудовими ресурсами у МСП. Результати сприяють подальшим дослідженням у сфері диверсифікаційного менеджменту, гендерної та вікової дискримінації працівників.

Ключові слова: диверсифікаційний менеджмент, організаційний менеджмент, управління персоналом, малий та середній бізнес.

Manuscript received: 29.11.2018.

(C) The author(s) 2019. This article is published with open access at Sumy State University. 